\title{
Evil, Child Abuse and the Caring Professions
}

\section{Caroline Humphrey}

\section{Abstract}

The aim of this paper is to explore the ways in which the concept of evil has been invoked in relation to child abuse. First, the scene is set by juxtaposing professional discourses which have eschewed the concept of evil and public opinion which is affronted by the evil of child abuse. Second, I will discuss the work of some therapists in the US whose work with perpetrators and survivors has led them to frame the causes and consequences of child abuse in terms of moral evil. Third, I will draw upon case studies of Satanic abuse and spirit possession in the UK to illustrate that some social workers and religious communities have interpreted child abuse as an outcome of or as an antidote to metaphysical evil. Finally, there is a critical appraisal of the merits of referencing moral and metaphysical evil in the discourses of caring professionals, with a suggestion that a mythicalmetaphorical conception of evil could be a more flexible and fruitful resource for therapeutic work.

KEY WORDS : evil, child abuse, caring professions 


\section{Evil, Child Abuse and the Caring Professions}

\section{Introduction}

Over three decades ago the US scholars James Garbarino and John Hershberger (1981) highlighted the 'morality gap' between the public view that child abuse constituted a reprehensible evil necessitating punishment, and the professional view that child abuse stemmed from socialisation deficits which were amenable to rehabilitation. This engendered a level of distrust between large segments of the public and caring professionals supposedly serving the interest of that public.

This morality gap remains entrenched. Professional discourses are formed at the juncture where the social sciences intersect with professional codes of ethics. Social scientific research into the causes and consequences of child abuse is framed exclusively in secular terms (Corby, 2005), which appears to render the concept of 'evil' superfluous insofar as it is embedded in religious discourses (Buchholz \& Mandel, 2000). Professional ethics emphasise the oppressive conditions impinging upon those who come to the attention of social workers, alongside the inviolable human rights of all people (IFSW \& IASSW, 2004), implying that to characterise perpetrators of child abuse as 'evil' is likely to circumvent their circumstances and rights and thence to do more harm than good. Public discourses among citizens, journalists and politicians continue to resurrect the spectre of evil in relation to child murders, even when the killers are themselves children. In the UK, this was most evident in 1993-94 during the trial of the 10-year-old boys who murdered a toddler James Bulger. The child-killers were dubbed 'freaks of nature' and 'products of the Devil' in the tabloids, and even described as 'evil' by the police officers who investigated the case, although the latter were well aware of the neglect and abuse in the backgrounds of those on trial (cited in Cole, 2006, pp. 125-126). So the public 
invocation of evil is a punitive one which disregards the stages of human life and the social conditions which contribute to the development of human morality. Philip Cole (2006) argues that such a 'monstrous' conception of evil represents a throwback to a mediaeval era, functioning as a moral condemnation of individuals which can neither further our understanding (because it is a descriptive label rather than an explanatory schema) nor facilitate their rehabilitation (because it deems them as outcasts of the human species and therefore beyond redemption). The chasm between publics and professionals becomes unbridgeable when social workers are regarded as having perpetrated a secondary form of evil by dint of their failure to recognise and respond to what in retrospect appear to be quite obvious indicators of child abuse in families (Elsley, 2010).

Caring professionals who want to make sense of evil in relation to child abuse in the 21st century will need to take account of two distinct developments. On the one hand, some clinicians in the independent sector in the US have applied the notion of moral evil to the causes and consequences of child abuse as a result of their work with perpetrators and survivors respectively. On the other hand, several statutory cases of child abuse in the UK have led social workers either to suspect that a metaphysical evil is at work (notably in Satanic rituals) or to realise that a belief in metaphysical evil on the part of some religious communities can contribute to child abuse (notably in spirit possession). The aim of this article is to examine these conundrums around moral and metaphysical evil in the US and the UK, mobilising case studies to provide concrete illustrations for readers unfamiliar with this territory. The distinction between moral and metaphysical evil will be retained for the sake of clarifying terminology in an arena characterised by conceptual confusion, although it is acknowledged that they may overlap since some who utilise the concept of evil testify to their interimbrication (i.e. moral-metaphysical evil - see Means \& Nelson, 2000). In the conclusion I will evaluate the merits of incorporating the concept of evil into the discourses of caring professionals. 


\section{Moral Evil}

Moral evil revolves around the deliberate infliction of suffering upon sentient beings who do not deserve such treatment (Goldberg, 1996; Zimbardo, 2004; Cole, 2006). The cause is rooted in human agency i.e. only human beings can distinguish between good and evil, and make choices in how to conduct themselves in the world, and this moral autonomy entails moral responsibility. Of course we do not make choices in a vacuum, and our moral capacities may be under-developed as a result of age or organic disability (Goleman, 2007), or undermined by circumstances ranging from domestic violence to repressive regimes (Zimbardo, 2004), so the inference that behind every 'evil deed' lurks an 'evil person' is unwarranted. Nevertheless, for most people character tends to consolidate over time as a result of a multiplicity of micro-moral choices in everyday life, until the constraints of habit outweigh the capacity to make new choices, so some adults can be said to have acquired an evil character which is resistant (rather than impervious) to change (Goldberg, 1996). Insofar as the suffering of victims entails an impairment of physical or mental health and sometimes a loss of life itself, the term 'moral evil' can also pertain to the consequences for victims. The tendency of evil to destroy the life-force of victims - and even that of their oppressors - is a central theme in the classic works on evil people by Erich Fromm (1968) and evil regimes by Hannah Arendt (1967).

Perpetrators of Child Abuse

Two clinicians in private practice in the US have deployed the concept of moral evil to certain categories of clients who are destructive towards those under their dominion such as their partners 
or children. However, their schema were not designed specifically to characterise perpetrators of child abuse, and even if the reader is persuaded of the validity of these schema, it should be remembered that only a proportion of perpetrators of child abuse would fit the relevant profile. Indeed, many parents who maltreat their children are struggling to do the best they can whilst suffering from broader societal evils such as poverty (Garbarino \& Hershberger, 1981; Corby, 2005).

Scott Peck was a psychiatrist who converted to Christianity a few years prior to publishing People of the Lie. The Hope for Healing Human Evil (1983). He proposes that 'evil' should be considered as a 'disease' in order to bring it under the microscope of scientific investigation and clinical treatment, and thus to avoid the dangers of persecuting those who fit the diagnostic criteria for evil -: "Although evil is antilife, it is itself a form of life. If we kill those who are evil, we will become evil ourselves; we will be killers." (ibid p. 306).

'People of the lie' is Peck's shorthand descriptor for those suffering the disease of evil, although it should be noted that it is typically other people in their dominion who consciously experience suffering, rather than 'people of the lie' who lie to themselves and others about their own virtuosity and therefore eschew the suffering associated with self-doubt and a sense of guilt. The 'evil personality' is defined as a variant of narcissistic personality disorder characterised by -:

1. The abrogation of personal responsibility

2. The scapegoating of others who are made to carry one's own sins

3. An intolerance to criticism and other forms of narcissistic injury

4. A pronounced concern with preserving a self-image and public image of respectability

5. The deployment of intellectual deviousness as a defence mechanism (ibid p. 146). 
Illustrative material is provided in the case study of a 15-year-old boy Bobby and his parents. Bobby presented as depressed, lifeless and expressionless, and had been brought to Peck by his parents after a period of self-harming which culminated in stealing and crashing a car. These difficulties had developed subsequent to the suicide of his elder brother the previous year. The brother killed himself with a rifle given to him by his parents, and the parents gave this same rifle to Bobby as his Christmas present, although Bobby had specifically asked for a tennis racket. The connection between these events was obvious to Peck, along with the non-verbal suggestion that Bobby should meet the same fate as his brother, but the parents refused to see that there might be any connection. Their self-defence was that they were good church-going people but only working-class, so they could not easily afford a tennis racket, and did not have access to the specialist training which would enable them to discern any such connection. Whilst Peck managed to secure an alternative form of kinship care for Bobby, he was unable to work with the parents (ibid pp. 52-76). Since all of the case studies demonstrate the resistance of 'people of the lie' to clinical intervention, the reader is left with scepticism about the therapeutic potential for 'healing human evil'.

A more comprehensive account of the development and treatment of moral evil is provided by the psychotherapist Carl Goldberg (1996) in Speaking with the Devil. A Dialogue with Evil. Contrary to the title of the book, Goldberg prefers the term 'the malevolent personality' to 'the evil personality', and repudiates any suggestion that clients who fit this description are the Devil personified (ibid pp. xi-xii). In his schema, the origins of the malevolent personality can be traced to childhood experiences of shame and trauma. These are internalised as self-contempt since children typically blame themselves when bad things happen, and are frequently blamed by adult carers as well, and some do come to construe themselves as 'children of the Devil'. When this self-contempt is unendurable, children try to conceal their badness from themselves and from the world, but this means that they have to cultivate a false facade and to avoid any introspection. By the same token, 
they fail to develop the language of emotions and ethics which could have helped them to make sense of their experiences. By adolescence and adulthood, they may become contemptuous of others as a way of casting off their own self-contempt, and anyone who inadvertently triggers their buried shame can become the victim of a violent attack. According to Goldberg (1996), adults enter therapy in order to salvage an intimate relationship or after being convicted of crimes of violence. Therapy commences with an attempt to recover repressed memories of trauma and shame from early childhood. Then it invites clients to process their experiences with reference to the language of emotions and ethics, which can include the reading of poetry, novels and religious scriptures. The overarching goal is to convince clients that they and everyone else they encounter are worthy of respect, so that they can relate differently in the world. The case studies offered by Goldberg (1996) indicate that this therapeutic dialogue is successful with clients at the earlier stages of developing a malevolent personality, although the client with a full-blown malevolent personality who was abusing his partner, and who had been involved in the murder of women and children in ethnic cleansing in Europe, literally fled a therapy session and never returned (ibid pp. 209-226).

Survivors of Child Abuse

Jeffrey Means and Mary Ann Nelson are Christian psychotherapists in a pastoral care setting in the US who specialise in working with adults who are survivors of child abuse and other trauma. They adopt a broad definition of evil in their work Trauma and Evil. Healing the Wounded Soul (2000) -:

"Evil disrespects and disregards the integrity of persons and tears them apart physically, psychologically, relationally and spiritually. Evil is present when people are objectified and then used and manipulated, rather than related to as the valued human beings they are" (ibid p.39). 
Children who have been physically, emotionally or sexually abused by a primary caregiver often believe that they harbour a destructive-demonic force inside themselves. According to the object relations theory underpinning the work of Means and Nelson (2000), this force is comprised of two elements. On the one hand, the rejecting caregiver has been introjected and now lives on inside the psyche of child and suppresses their life force from within. On the other hand, the child's own terror and rage at having been violated, along with shame at having been powerless to prevent the abuse, forms a cauldron of raw emotions which can never be resolved within the context of an abusive family. This destructive-demonic force is the wellspring for mental health problems in later life. For example, it may become a persecutory alter ego which endlessly rebukes and ridicules the person, and it is not unusual for a survivor to resort to self-harm, suicide attempts or drug-induced stupors in an effort to pacify or nullify their destructive-demonic force. But it may also become a vehicle for converting victims into persecutors, and some survivors of childhood abuse unleash their destructive-demonic force upon the next generation of children.

Means and Nelson (2000) asseverate that although trauma and evil are not synonymous, the signs of evil can be decoded from the effects of trauma upon the victim, since evil compounds trauma in a manner which prevents the victim from accessing healing resources from within or without. This is illustrated by the story of a young woman who had been sexually abused by a male cousin since the age of six - the sexual abuse is the primary trauma, and subsequent events demonstrated that it was surrounded by evil. As a child, she had told her parents about the abuse; initially they refused to believe her, and later they claimed that if anything had happened it must have been her fault. This parental response operated as a form of evil, since it sabotaged the girl's access to external resources for resistance, enabling the cousin to continue the sexual abuse into her late adolescence. Over time she started to hear voices telling her that she was so evil she should die, and she developed cutting rituals as a desperate self-defence and self-healing strategy. The cousin then 
deployed these internal resources against his victim - after raping her, he would tell her to go and cut herself again as she hadn't yet gone deep enough, thus compounding trauma and evil in a single deed (ibid p. 91).

The work of healing involves revisiting such trauma and reintegrating split-off parts of the self. Whilst it is paramount that victims appreciate that they are not evil and did not deserve such treatment, ideally survivors would remain in therapy for long enough to move beyond the dichotomy between 'good victims' and 'evil perpetrators' in realising that all of us carry the potential for both good and evil (Means \& Nelson, 2000).

\section{Metaphysical Evil}

Metaphysical evil has its source in a supra-natural and supra-human dimension of the cosmos. The majority of religious and spiritual traditions foster a belief in a metaphysical realm, and the opposition between the transcendent forces of Good and Evil (or God and Satan) is particularly pronounced in Christianity and Islam, although there is a more ambivalent relationship between good and evil in Judaism (Buchholz \& Mandel, 2000) and indigenous cultures across the globe (Parkin, 1985). In the metaphysical realm there may also be a range of intermediate beings such as angels, demons and ancestors. Whilst their powers are derivative from the supreme powers of Good and Evil, it may be easier for human beings to influence or be influenced by intermediate beings which are closer to the earth plane (e.g. Dein, 2009). Two types of child abuse cases in the UK have brought metaphysical evil to the attention of caring professionals - i.e. Satanic abuse and spirit possession - although it should be noted at the outset that these phenomena have been incubated within a global context. 
Satanic Rituals

Modern Satanism emerged in the early 20th century as a result of the work of Aleister Crowley who travelled across Europe practising the 'Black Mass' and 'sex magick' and claiming to sacrifice animals, babies and children in Satanic rituals, claims which both his followers and detractors regarded as wildly exaggerated and designed to solicit the attention of an outraged public. It resurfaced in the US in 1966 when Anton LaVey established the Church of Satan; this is a recognised religion in the US and has given birth to a variety of small Satanic groups in the US and the UK (Tate, 1991). During the 1970s and 1980s a Christian revivalist movement arose to combat the evil of Satanism, but in the process it tended to treat all new-age religions as manifestations of Satanism (La Fontaine, 1998). At the same time adults undergoing hypnotic forms of therapy in the US recovered memories of Satanic abuse during childhood involving sex, murder and cannibalism. However, police officers failed to find corroborative evidence of these rituals, and eventually the psychiatric establishment conceded that such patients were highly susceptible to the suggestions of therapists, and highly sensitive to media stories, so that they may have fabricated or at least embellished some of their stories and symptoms (Mulhern, 2009).

It was perhaps inevitable that cases of Satanic abuse would appear in relation to children. In 1982 in Shropshire, UK, two men were convicted of the sexual abuse of children during Satanic rituals, aided and abetted by their wives who had dedicated their lives to Satan. In court one of the men identified himself as Lucifer and the eldest child, a 15-year-old girl, reported rituals which entailed being subjected to vaginal and anal sex with both men on an alter and having an inverted cross branded on her torso. Younger children including a baby had also been subject to abusive rituals, although they 
were too young to provide evidence in court (Tate, 1991). Over the next decade, cases involving similar forms of ritual abuse emerged across the UK, and the government commissioned Jean La Fontaine to investigate all such cases over a five-year period 1987-1992. She studied case records and court transcripts pertaining to 84 cases of alleged ritual abuse, and interviewed some of the social workers, police officers and foster carers involved in these cases (La Fontaine, 1994, 1998).

These cases tended to involve extended families where several children were sexually and physically abused by several adults. They also featured a polarisation of professional opinion, so that social workers, therapists and foster carers typically believed that these children had been abused during Satanic rituals, whilst police officers, lawyers and academics were scathing about such allegations and disregarded them for all practical purposes. La Fontaine (1998) uncovered a few cases where older children reported rituals such as having sex with animals and having their bodies brandished, but the vast majority of parents had no involvement in Satanism or any other religious movement. Since the average age of the traumatised children was six years, their stories were often fragmented, so that only the superimposition of adults' interpretations could render them coherent.

The consequence is that the majority of the cases were amenable to a secular explanation. First, many parents and perpetrators exploited children's beliefs in the supernatural by dressing up as horned beasts and ghosts during the abuse, which served the dual purpose of intimidating the children into submission and concealing the identities of the perpetrators. Second, young children often conflated virtual and actual realities - for example, when adults forced them to watch sadomasochistic videos, they recounted stories of torture chambers and violence 'as if' they had directly participated in these events. Third, foster carers felt that the children's behaviour in care was sufficiently bizarre that they must have been subjected to a distinctive form of child abuse, and the 
media coverage of Satanic abuse at the time exerted its own influence over their interpretations - so when two boys aged six and four years simulated anal intercourse, their foster carer concluded that they were re-enacting a Satanic ritual. Finally, the lead social workers in some cases subscribed to a belief in Satanic abuse, and subjected children to repeat interviews on the assumption that there would be greater resistance to disclosing Satanic abuse than ordinary sexual abuse. One girl had been subject to 80 hours of interviews until the 'correct' disclosure was forthcoming, and one judge was scathing about such leading interviews (La Fontaine, 1998).

La Fontaine's (1998) argument is that the belief in the reality of Satanic evil among professionals was the interpretative context for severe cases of child sexual abuse in the UK in the 1980s-90s, and that it acted as a self-fulfilling prophecy in many of these cases. A similar phenomenon may operate in the US insofar as cases of ritual and religious abuse predominate in the Bible Belt (Bottoms et al., 1996). Of course this does not mean that there is no such thing as Satanic abuse. Rather, such cases can be inflated or created by beliefs in Satanism (or suppressed by its denial). But let us inspect whether Satanic abuse actually constitutes a form of metaphysical evil in any event.

Contrary to popular and Christian discourses, Satanists do not espouse a belief in any kind of metaphysical realm and are not calling upon the power of a transcendent Evil. LaVey (1969) is adamant that human beings have always created their own gods as projections of their own ideals so that they are only worshipping themselves by proxy, and Satanists have chosen to regard the mythical figure of Satan as their ideal, as this is most congruent with their desire to celebrate all the human vices associated with traditional moralities, both secular and religious. Satanism is an earthly egotism, as exemplified by Crowley's maxim "Do what thou wilt shall be the whole of the Law" (cited in Tate, 1991 p. 94). The Satanic rituals are ways of dramatising the 'sins' of lust and revenge in 
collective orgies and the casting of curses, although there is, perhaps paradoxically, a belief in the magical power of such rituals to influence wider events (LaVey, 1969). If we accept these selfdescriptions, Satanic rituals may be rooted more in moral-mythical evil than in metaphysical evil.

Spirit Possession

Victoria Climbié was an African girl who was sent to live with an aunt in the UK to enhance her lifechances, but who died of malnutrition and maltreatment in 2000 at the age of eight years. The family moved between various London boroughs and attended a number of black churches; some injuries were clearly visible on the child, but the pastors accepted the aunt's claim that she had inflicted injuries in order to cure the girl of the evil spirits that possessed her; indeed, a deliverance ritual or exorcism had been arranged on the day of her death (Laming, 2003). Allegations of spirit possession had featured in other child abuse cases, prompting the government to commission a research report from Eleanor Stobart (2006). She uncovered 74 cases of spirit possession over a five-year period 2000-2005, and selected those where full case records were available for her indepth study of 38 families with 47 children.

Stobart (2006) found that most of these families had arrived in the UK from African countries, although some were from the Asian continent and the Caribbean, and most them combined their indigenous beliefs with a mainstream Western religion, usually Christianity but sometimes Islam. Acculturation could be a complex affair as high aspirations for a better life floundered on the rocks of racial discrimination, and many families sought refuge in black churches, which served to reinforce supernatural explanations of maladies and recourse to supernatural remedies. Essentially, one or more children in the family were blamed for bringing about the family's misfortunes. This 
assumed two forms - child-witches were believed to have invited an evil spirit into themselves to enhance their own powers to wreak havoc on their families, whilst child-victims were believed to have been colonised by an evil spirit against their will. This established the interpretative context within which relatively innocuous or readily explicable phenomena could become sinister signs of an evil at work - for example, a child who dreamed of returning to her country of origin was deemed to be a witch with powers of transmigration. Stobart's (2006) case studies reveal that the abuse of the children escalated over time as parents resorted to increasingly harmful practices. Initially they would ostracise the child and request deliverance rituals from their religious leaders. When the child's behaviour deteriorated, tribal remedies would come into play - for example, rubbing chilli peppers into bodily orifices on the grounds that these are repugnant to evil spirits; beating, burning or cutting the child to drive the evil spirits out of the body; and starving or semi-strangulating the child to deprive the evil spirits of nutrients and oxygen. Eventually social workers were notified and they instigated legal action to remove the children. Some parents were relieved by this, but others sent the children back to their country of origin where they died or disappeared without trace.

Anthropologists have long testified to the syncretism of indigenous witchcraft and Christian demonology in African states where missionary activity was successful, but the idea that children could be witches is of recent origin. La Fontaine's (2009) summary of contemporary research in central Africa highlights the convergence of the following factors. First, the spectre of the child-witch has emerged in states which are undergoing the turbulence of civil wars, so that some older children decided to become soldiers or diamond hunters, dislodging adults' conviction in the innocence of childhood. Second, poor people continue to locate the causes of extreme suffering which are beyond their comprehension in a metaphysical realm. Third, there has emerged a new brand of Pentecostalism with a strong conviction in demonology and deliverance, where material success is interpreted as a sign of God's favour, and material misfortunes as a sign of the Devil's work. 
Unfortunately, some pastors have exceeded this remit by declaring that some children derive from 'demon seed'. According to La Fontaine (2009), dispossessed families can easily be persuaded that the Devil has targeted them via one or more of their children, whether they remain in Africa or become refugees abroad.

Deliverance rituals are undertaken routinely in Pentecostal churches across the globe, and most revolve around prayers, chanting and symbolic actions to destroy the enemy without any abuse of parishioners deemed to be 'possessed'-:

“We do deliverance prayers (a form of exorcism) as warfare ... Only if children's abnormal behaviour coincides with misfortunes in their family are children thought of as witches. Beating them will not change anything; only the power of prayer, the power of the Word, the power of the Name and of the blood or of the Cross could rid them of the evil" (Magbagbeola, 2009 p. 112).

Of course the belief in metaphysical evil is not harmful in itself - rather, the maltreatment of children is harmful, howsoever justified (Department for Education and Skills, 2007). The problem for professional practice is that the beliefs of secular professionals and faith-based communities are as dissonant from each other as they are deep-rooted. Briggs et al. (2011) have followed the work of four organisations which have been engaging parents, young people, pastors and parishioners in African communities across London in debates about child rearing, children's rights, child protection policies and religious traditions. These organisations are The Victoria Climbié Foundation, the Congolese Family Centre, AFRUCA (Africans United against Child Abuse) and the Churches' Child Protection Advisory Service. At times staff from these organisations encounter opposition from parents and pastors. It can assume the guise of a defensive denial to the effect that child abuse does not exist in the relevant community, or a guarded secrecy so that parents revert to their native 
language when asked to discuss the topic of witchcraft and spirit possession. It can also take the form of overt hostility, so that when staff from one organisation attended church services, one was dubbed 'The Anti-Christ' and another received death threats. Child care professionals can also be subject to such religious hostility. The Churches' Child Protection Advisory Service reported a case of parents who believed that their autistic teenage son was possessed by an evil spirit and therefore refused the package of health, educational and social care services offered to him on the grounds that these were irrelevant to the problem. Social workers offering a secular support package were regarded as having been sent by the Devil, and eventually they had to take court action to remove the boy (Briggs et al., 2011). Nevertheless, this pioneering cross-cultural dialogue continues, as it represents our best hope for bridging and healing the gulf between child protection professionals and African communities in the UK.

\section{Conclusion}

The twin concepts of good and evil are linked by an umbilical cord in our language and thought, and have shaped cultural histories across the globe, so that it would be neither possible nor desirable to extirpate the 'negative' polarity. But it is incumbent upon us to elucidate the meaning of evil and the consequences of invoking it in any given context or case, and here I venture to do so in relation to the discourses of caring professionals and the phenomenon of child abuse.

First, moral evil ought to be taken just as seriously by caring professionals as moral goodness if the umbilical cord between these concepts is to be honoured. Professional codes of ethics in social work vaunt the good which the profession seeks to promote, and construe society as the source of the poverty or pathology which afflicts clients, but they would benefit from acknowledging that evil is 
also rooted in the human psyche which has always already moulded the shape of society even as it is in turn constituted by the structures and cultures of that society (cf. Garbarino \& Hershberger, 1981; IFSW \& IASSW, 2004). The idea that the abuse of children is one of the greatest moral wrongs is inherent in the work of child protection professionals, and it may be only a short step to regard some recidivist offenders as 'evil' or to portray the effects upon traumatised survivors as 'evil'. Nevertheless, the morality gap between professional and public discourses may be transmuted into a signification gap insofar as caring professionals would utilise the term 'evil' to denote something rather different from both punitive publics and religious communities by virtue of their commitment to humanistic ethics and social scientific research. In particular, caring professionals should be cognizant that the term 'evil' is more of a descriptive label than an explanation so that it signals the beginning of an evidence-gathering adventure rather than its end-point (Cole, 2006), and that these polar extremes are 'ideal types' constructed by human thought, so that in reality all human beings inhabit the vast murky realm where good and evil interpenetrate (Buchholz \& Mandel, 2000).

Second, metaphysical evil has proven to be deeply problematic in recent decades. When beliefs in metaphysical evil were reactivated in the UK by the moral panic around Satanic abuse, they exerted such a strong influence over social workers' interpretative schema that evidence-based practice was jeopardised. When human beings are treated as the harbingers of metaphysical evil they become 'demons' or 'monsters' rather than human beings, and children have been murdered as a consequence of parents' beliefs in evil spirits. Agnosticism on the question of metaphysical evil is advisable for professionals who need to remain grounded in evidence-based practice and humanistic ethics, and open to dialogues with individuals and communities exhibiting diverse world-views. Such an agnosticism requires that both religious convictions and atheist disbelief are bracketed for the sake of conducting investigations or therapy, and this in turn presupposes that caring professionals have subjected their personal world-views to critical scrutiny, something which their secular training 
may have discouraged. This mandates educators to incorporate religion into the curriculum as integral to enhancing professional ethics and practice in multi-cultural societies - this has been lamentably absent from social work training in the UK, which lags behind the US in this respect (cf. Canda \& Furman, 1999; Furman et al., 2004). If this education is effective, it should free us up to think in a more creative and critical manner about both religious and scientific world-views.

Third, one way of freeing up our thinking around evil is to approach it as metaphor and myth. The language of metaphor and myth comes into its own when we are trying to make sense of and give expression to things which surpass our understanding. Moral evil can be approached as a metaphor for aspects of the human psyche which escape our understanding - indeed, crimes are dubbed 'evil' when they seem senseless as well as abhorrent. It is interesting to compare this to 'the shadow' in Jung's psychology. This represents those aspects of ourselves which we choose to conceal from others and even ourselves on the assumption that they are morally reprehensible. Healthy development is about learning to shine the light of consciousness on our own shadow, to remove the excesses of darkness, and to integrate the residues of darkness into our conscious selves. Only then can we recognise the complexity of being human, prevent the projective dynamics of casting our own shadow onto others, and preserve compassion for those who continue to live in the darkness, and who may feel compelled to cast their own shadow onto others (Daniels, 2005). The term 'shadow' is deployed metaphorically i.e. we cannot see a shadow, or the light of consciousness, and neither will show up on a brain scan, but it is only this metaphorical language which enables us to make sense of the opaque complexity of the psyche. There is no suggestion that moral evil is 'merely' a metaphor; the point is rather that a metaphorical use of language may be more conducive to our education and enlightenment than a literal one. To believe oneself to be literally evil, or to be told that one is truly evil, may itself be a terrible curse, inviting the response of either suicide (insofar as there is no redemption from evil) or refusal to change (insofar as self-preservation cuts in). To 
think of oneself as harbouring a shadow which predominates in one's psyche at certain times, so that one sometimes acts 'as if' one is evil, allows more scope for distancing oneself from this shadow and reflecting upon how one has acted in the world, and this capacity for detached observation operates as the fulcrum for therapeutic change. In a similar vein, metaphysical good and evil in the shape of God and Satan can be considered as a myth for making sense of Good and Evil on a cosmic scale. This does not mean that Good and Evil do not exist in a supra-human, supra-natural cosmic reality; it is rather that since they are inexorably beyond the reach of the human senses and sciences, it is more apt to cultivate a mythical language to depict them than a literal one.

The importance for caring professionals is that both evil and good can become resources for healing. For example, when a client confessed that he saw 'the Devil' when he looked in the mirror, Goldberg (1996) retrieved paintings of demons in a mediaeval text and the client identified one of them as the face he saw in the mirror. In effect, this demon represented his shadow self, and the therapist and client entered into a dialogue with it, until the client managed to acknowledge it as part of himself, as the necessary prerequisite for controlling it and choosing how to deal with it (ibid. pp. 89-109). Likewise, play and art therapy with children who have been abused is about encouraging them to express their experiences and emotions. Children readily make use of angels and demons to symbolise their experiences of being caught up in a conflict between good and evil, not only when these figures are available as concrete objects in a sand-tray, but also when they are free to paint their own pictures to represent their situation (Morris, 2002). Of course this quest is not confined to clients or children - the battle between good and evil is endemic to science fiction and fantasy literature and films as well as computer games which attract audiences across the social spectrum. The language of metaphor and myth expresses emotional, ethical and existential truths which transcend sensory, factual and scientific truths - and both of these languages belong in the caring professions insofar as they are equally vital to understanding and healing our human maladies. 


\section{References}

Arendt, H. (1967). The origins of totalitarianism. London: Allen \& Unwin.

Bottoms, B., Shaver, P. R. \& Goodman, G. S. (1996). An analysis of ritualistic and religion-related child abuse allegations. Law and Human Behaviour, 20 (1), 1-34.

Briggs, S., Whittaker, A., Linford, H., Bryan, A., Ryan, E. \& Ludick, D. (2011). Safeguarding children's rights: exploring issues of witchcraft and spirit possession in London's African communities. London: Trust for London, Centre for Social Work Research, Tavistock \& Portman NHS Foundation Trust \& University of East London.

Buchholz, E. S. \& Mandel, J. K. (2000). Reaching for virtue, stumbling on sin: concepts of good and evil in a postmodern era. Journal of Religion and Health, 39 (2), 123-142.

Canda, E. R. \& Furman, L. D. (1999). Spiritual diversity in social work practice. The heart of helping. New York: Free Press.

Cole, P. (2006). The myth of evil. Edinburgh: Edinburgh University Press.

Corby, B. (2005). Child abuse: towards a knowledge base. Buckingham: Open University Press (3rd edition).

Daniels, M. (2005). Shadow, self, spirit. Essays in transpersonal psychology. Exeter: ImprintAcademic.

Dein, S. (2009). 'The jinn, black magic and evil eye among East London Bangladeshis'. In J. S. La Fontaine (Ed.), The Devil's children. From spirit possession to witchcraft: new allegations that affect children (pp. 77-90). Farnham: Ashgate. 
Department for Education and Skills (2007). Safeguarding children from abuse linked to a belief in spirit possession. London: DfES.

Elsley, S. (2010). Media coverage of child deaths in the UK. The impact of Baby P : a case for influence? University of Edinburgh: Centre for UK-Wide Learning in Child Protection.

Fromm, E. (1968). The heart of man. Its genius for good and evil. London: Harper \& Row.

Furman, L. D., Benson, P. W., Grimwood, C. \& Canda, E. (2004). 'Religion and spirituality in social work education and direct practice at the millennium : a survey of UK social workers', British Journal of Social Work, 34 (6), 767-792.

Garbarino, J. \& Hershberger, J. (1981). 'The perspective of evil in understanding and treating child abuse', Journal of Religion and Health, 20 (3), 208-217.

Goldberg, C. (1996). Speaking with the Devil. A dialogue with evil. New York: Viking.

Goleman, D. (2007). Social intelligence. The new science of human relationships. London: Arrow Books.

International Federation of Social Workers \& International Association of Schools of Social Work (2004). Ethics in social work - statement of principles. Available at www.ifsw.org/f38000032.html Accessed 4th March 2012.

Laming, Lord (2003). The Victoria Climbié Inquiry. London: The Stationary Office.

La Fontaine, J. S. (1994). The extent and nature of organised and ritual abuse. Research findings. London: Her Majesty's Stationary Office.

La Fontaine, J. S. (1998). Speak of the Devil. Tales of Satanic abuse in contemporary England. Cambridge: Cambridge University Press. 
La Fontaine, J. S. (2009). Child witches in London: tradition and change in religious practice and belief'. In J. S. La Fontaine (Ed.), The Devil's children. From spirit possession to witchcraft: new allegations that affect children (pp. 117-127). Farnham: Ashgate.

LaVey, A. S. (1969). The Satanic Bible. New York: Avon Books.

Magbagbeola, M. (2009). Possession in the Celestial Church of Christ. In J. S. La Fontaine (Ed.), The Devil's children. From spirit possession to witchcraft: new allegations that affect children (pp. 109113) Farnham: Ashgate.

Means, J. J. \& Nelson, M. A. (2000) Trauma and evil. Healing the wounded soul. Minneapolis: Augsberg Fortress.

Morris, J. (2002). Heroes' journeys : children's expression of spirituality through play therapy. In M. Nash \& B. Stewart (Eds.), Spirituality and social care. Contributing to personal and community wellbeing (pp. 189-214). London: Jessica Kingsley.

Mulhern, S. (2009). Embodied alternative identities: spiritual possession, psychiatric disorder or socio-/political strategem? In J. S. La Fontaine (Ed.), The Devil's children. From spirit possession to witchcraft: new allegations that affect children (pp. 37-60). Farnham: Ashgate.

Parkin, D. (1985) Introduction. In D. Parkin (Ed.), The anthropology of evil (pp. 1-25). Oxford: Basil Blackwell.

Peck, M. S. (1983). People of the lie. The hope for healing human evil. London: Arrow.

Stobart, E. (2006). Child abuse linked to accusations of 'possession' and 'witchcraft'. London: The Stationary Office.

Tate, T. (1991). Children for the Devil. Ritual abuse and Satanic crime. London: Methuen. 
Zimbardo, P. G. (2004). A situationalist perspective on the psychology of evil: understanding how good people are transformed into perpetrators. In A. G. Miller (Ed.), The social psychology of good and evil (pp. 21-50). New York: Guildford Press. 